Bangladesh J. Sci. Res. 28(1): 9-16, 2015 (June)

\title{
SEASONAL VARIATION IN QUALITY OF LOUHAJONG RIVER WATER, TANGAIL
}

\author{
Md. Rakib Hasan Sarker, Asadul Islam, Ariful Islam, Md. Mahbubul Hoque and Shimul Roy* \\ Department of Environmental Science and Resource Management, \\ Mawlana Bhashani Science and Technology University, Tangail-1902, Bangladesh
}

\begin{abstract}
Water samples were collected from three points of Louhajong river (Dighulia, Kagmari Bridge and Oloa) to see the seasonal variation in physico-chemical parameters. The results revealed that some of the parameters such as TDS, alkalinity and acidity have exceeded the standard level in dry season in all of the points, which are unsuitable for different purposes including fish culture. During dry and wet seasons the highest concentrations of BOD was recorded as 2.0 and 0.8 ppm at Kagmari Bridge (point-2) respectively. DO ranged from 1.4 to 3.1 and 2.4 to 3.8 ppm during dry and wet seasons. Maximum and minimum EC was recorded as 890 and $130 \mu \mathrm{s} / \mathrm{cm}$ at Dighulia (point-1) during dry and wet seasons. The results suggest that at wet season Louhajong river may be suitable for fish culture and other purposes.
\end{abstract}

Key words: Louhajong river, Water quality, Dry-wet season

\section{Introduction}

The surface water resource is very much essential for a country especially for its human and animal living, aquatic flora and fauna, navigation, agriculture, etc. It is also necessary for keeping alive the distributaries in the delta and maintaining ecosystem along the sea, on an annual cycle (Razo et al. 2004, Haque 2008). It has become an essential commodity for the development of industries and agriculture (Kudesia 1990).

Bangladesh is one of those polluted countries, which currently holds 1176 industries that discharge about 0.4 million $\mathrm{m}^{3}$ of untreated waste to the rivers in a day (Rabbani and Sharif 2005). The increasing urbanization and industrialization of Bangladesh have negative implications for water quality where the industrial effluents directly dispose into the rivers without any consideration of the environment (BCAS 2004). Water of the Louhajong river is mainly used in agricultural purposes and plays a vital role in the economy of the Tangail region of Bangladesh. As the fluvial environment of Bangladesh is mainly controlled by seasonal fluctuations, it is important to characterize the seasonal change for evaluating the temporal variations of water pollution (Bhuiyan et al. 2010). The objective of the study was to determine the status of water quality of Louhajong river by assessing the physico-chemical parameters in dry and wet seasons.

\section{Materials and Methods}

During May (dry season) and August (wet season) samples were collected from three points and each point consists of three stations namely Dighulia (Point 1; P-1), Kagmari Bridge (Point 2; P2), and Oloa (Point 3; P-3). At a distance of about 500 meters from each other samples were collected in $250 \mathrm{ml} \mathrm{HCl}$ washed plastic bottles.

*Corresponding author: <shimul_esrm@yahoo.com>. 
To analyze the samples standard methods were followed. $\mathrm{pH}$ was determined by the digital pH meter (Model: AD 1000); EC by the EC meter (Model: HANNA instruments), Total dissolved solid (TDS) was measured by TDS meter (Model: HM Digital); DO by digital DO meter (ModelD. 46974, Taiwan) using sodium thiosulphate $(0.025 \mathrm{~N})$; alkalinity, acidity and hardness by titrimetric analysis. BOD was estimated according to Trivedy and Goel (1984), where initial BOD $\left(\mathrm{BOD}_{1}\right)$ was measured immediately after collecting the sample and $\mathrm{BOD}\left(\mathrm{BOD}_{5}\right)$ was measured after incubation of water sample in the dark at $20^{\circ} \mathrm{C}$ for 5 days. The color and temperature of the collected samples were measured visually and by thermometer respectively.

\section{Results and Discussions}

The water color in Digulia point was observed black, which may be due to the dumping of urban and domestic waste and that in Kagmari point, was slightly greenish, which may be for the enrichment of phytoplankton. Das (1997) asserted that phytoplankton enriched dark greenish blue, red or brown color is good for fishes. However, the water was totally unsuitable not only for aquaculture but also for domestic, industrial or agricultural purposes.

Table 1. Water quality parameters of the Louhajong River in dry season.

\begin{tabular}{lccccccccc}
\hline & \multicolumn{1}{c}{ Name of points } \\
\cline { 2 - 10 } Parameters & \multicolumn{7}{c}{ Dighulia (P-1) } & \multicolumn{1}{c}{ Kagmari Bridge (P-2) } & \multicolumn{3}{c}{ Oloa (P-3) } \\
\cline { 2 - 10 } & S-1 & S-2 & S-3 & S-1 & S-2 & S-3 & S-1 & S-2 & S-3 \\
\hline Temp. $\left({ }^{0} \mathrm{C}\right)$ & 23 & 24.8 & 22 & 26 & 24 & 25 & 26.5 & 26 & 25.5 \\
pH & 6.88 & 6.83 & 6.91 & 6.99 & 6.82 & 6.87 & 7.05 & 7.12 & 7.24 \\
EC $(\mu \mathrm{S} / \mathrm{cm})$ & 790 & 890 & 860 & 720 & 750 & 720 & 310 & 290 & 310 \\
TDS (ppm) & 482 & 493 & 532 & 447 & 475 & 429 & 189 & 185 & 188 \\
DO " & 1.8 & 1.6 & 1.4 & 2.9 & 3.1 & 2.8 & 2.3 & 2.1 & 2.3 \\
BOD " & 1.2 & 1.0 & 0.8 & 1.8 & 2.0 & 1.7 & 0.6 & 0.4 & 0.6 \\
Hard. (mg/l) & 100 & 108 & 114 & 164 & 168 & 172 & 168 & 172 & 176 \\
Alk " & 326 & 332 & 320 & 278 & 270 & 282 & 154 & 156 & 162 \\
Acid. " & 268 & 276 & 272 & 116 & 122 & 128 & 58 & 64 & 72 \\
\hline
\end{tabular}

P = Points. $\mathrm{S}=$ Stations. Temp. = Temperature. Hard. = Hardness. Alk. = Alkalinity. Acid. = Acidity.

During dry season (May) the highest $\left(26.5^{\circ} \mathrm{C}\right)$ and lowest $\left(22^{\circ} \mathrm{C}\right)$ temperatures were recorded at Oloa (P-3) and Dighulia (P-1) (Table 1), respectively whereas in wet season the highest $\left(25^{\circ} \mathrm{C}\right)$ and lowest $\left(21^{\circ} \mathrm{C}\right)$ temperatures were also recorded at Oloa (P-3) and Dighulia (P-1) respectively (Table 2). 
The electrical conductivity (EC) is usually used for indicating the total concentration of charged ionic species in water (Rahman et al. 2012). The area under study shows the lower value of EC during dry and wet seasons in accordance with the FAO drinking water standard for EC (1000 $\mu \mathrm{s} / \mathrm{cm})$. Rahman et al. (2012) worked on Turag river water quality also showed the similar results. However, the highest and lowest values of EC (890 and $130 \mu \mathrm{s} / \mathrm{cm}$ ) were observed at Dighulia (P-1) (Tables 1-2) during dry season and wet seasons.

Table 2. Water quality parameters of the Louhajong River in wet season.

\begin{tabular}{lccccccccc}
\hline & \multicolumn{7}{c}{ Name of points } \\
\cline { 2 - 11 } Parameters & \multicolumn{7}{c}{ Dighulia (P-1) } & \multicolumn{7}{c}{ Kagmari Bridge (P-2) } & Oloa (P-3) \\
\cline { 2 - 11 } & S-1 & S-2 & S-3 & S-1 & S-2 & S-3 & S-1 & S-2 & S-3 \\
\hline Temp. $\left({ }^{0} \mathrm{C}\right)$ & 22 & 23 & 21 & 23 & 22 & 24 & 24 & 25 & 23 \\
pH & 7.48 & 7.56 & 7.63 & 7.49 & 7.56 & 7.52 & 7.59 & 7.72 & 7.69 \\
EC $(\mu \mathrm{S} / \mathrm{cm})$ & 150 & 130 & 140 & 190 & 220 & 230 & 270 & 240 & 280 \\
TDS (ppm) & 85 & 89 & 81 & 84 & 86 & 88 & 84 & 92 & 88 \\
DO " & 3.7 & 3.8 & 3.5 & 3.2 & 2.9 & 2.7 & 2.4 & 2.5 & 2.4 \\
BOD " & 0.6 & 0.7 & 0.4 & 0.8 & 0.5 & 0.3 & 0.3 & 0.4 & 0.3 \\
Hard. (mg/l) & 112 & 106 & 108 & 218 & 212 & 210 & 248 & 254 & 252 \\
Alk. " & 68 & 72 & 74 & 56 & 62 & 66 & 76 & 78 & 82 \\
Acid. " & 48 & 44 & 44 & 42 & 44 & 44 & 26 & 32 & 28 \\
\hline
\end{tabular}

P = Point. $\mathrm{S}=$ Station. Temp. $=$ Temperature. Hard. $=$ Hardness. Alk. = Alkalinity. Acid. $=$ Acidity

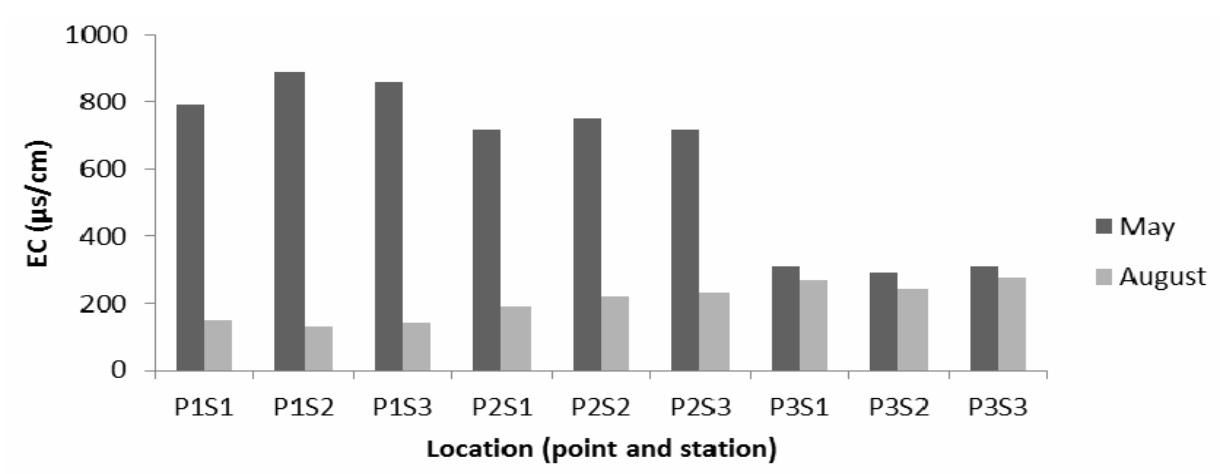

Fig. 1. Variation of EC in the experimental points and stations during May and August.

The BOD was higher in Kagmari Bridge (P-2) at station 2(S-2) as compared to all other points (Fig. 2), which may be due to the presence of some industries and increased urbanization in that area. In most of the points higher values of BOD were observed during the dry season. 
Rahman et al. (2012) also showed similar results of BOD due to the seasonal variations. During dry season the highest concentration of BOD (2.0 ppm) was found in Kagmari Bridge (P-2) at station 2(S-2) (Table 1) whereas that in wet season was $0.8 \mathrm{ppm}$ in the same point (P-2) but at station 1(S-1) (Table 2). However, BOD concentration in Oloa (P-3) at station 2 (S-2) was found to be $0.4 \mathrm{ppm}$ both in the dry and wet seasons (Tables 1 and 2).

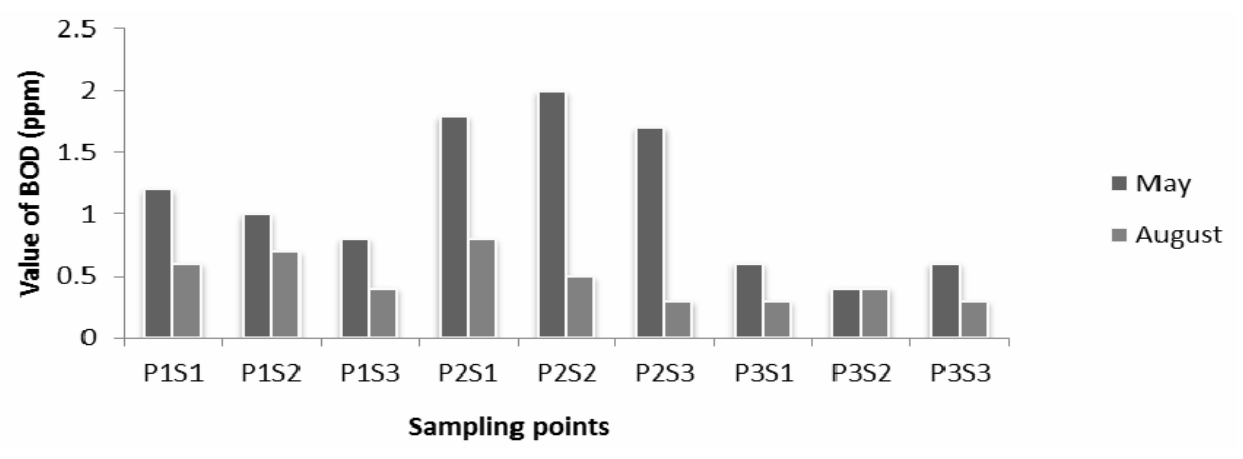

Fig. 2. Variation of BOD in the experimental points and stations during May and August.

An adequate supply of DO is essential for the survival of aquatic organism (Dara 2002). When BOD levels are high, dissolved oxygen (DO) levels decrease because the oxygen that is available in the water is being consumed by the bacteria (Sawyer et al. 2003). Since less dissolved oxygen is available in the water, fish and other aquatic organisms may not survive. If there is no organic waste present in the water, there would not be as many bacteria present to decompose it and thus the BOD will tend to be lower and the DO level will tend to be higher (Rahman et al. 2012). The environmental quality standard (EQS 1997) prescribed the following requirements for DO: $6 \mathrm{mg} / \mathrm{l}$ for drinking, 4 to $5 \mathrm{mg} / \mathrm{l}$ for recreation, 4 to $6 \mathrm{mg} / \mathrm{l}$ for fish and livestock and $5 \mathrm{mg} / \mathrm{l}$ for industrial application. The results showed that DO values ranged from 2.4 to 3.8 and 1.4 to 3.1 ppm during wet and dry seasons (Fig. 3). The highest and lowest DO values (3.8 and 1.4 ppm) were observed at Dighulia (P-1) in wet and dry seasons (Tables 1 and 2). According to Boyd (1982), fluctuations in DO concentrations might be due to alteration in the rate of photosynthesis caused by altering cloudy and sunny weather of the monsoon and also due to variation in the rate of oxygen consumption by fish and other aquatic organisms.

The measured $\mathrm{pH}$ value in Louhajong river was greater than 7 at wet season and lower than 7 at dry season (Fig. 4), whereas the standard of pH is 6 to 9 (ECR 1997). This might be due to the domestic and industrial wastes disposal in the bank of the Louhajong river. The highest $\mathrm{pH}, 7.72$ was found at Oloa (P-3) in August (Table 2), and the lowest $\mathrm{pH}$ value, 6.91 at the Kagmari Bridge in May (Table 1). An alkaline environment with a $\mathrm{pH}$ range between 7.5 and 8.4 is good for the growth of algae and range between 6.0 and 7.2 is optimum for fish eggs (EGIS II 2002). The observed values reflect its suitability for aquatic life and for all other purposes like irrigation, 
domestic and recreational. Rahman et al. (2012) also showed similar results of $\mathrm{pH}$ ranging from 6.6 to 7.85 and is suitable for diversified uses.

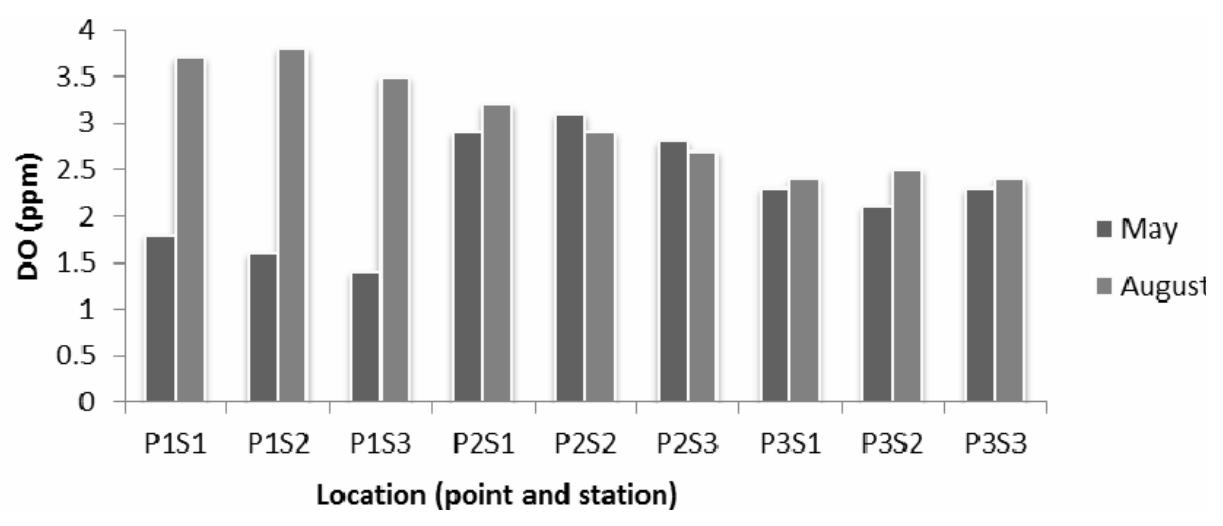

Fig. 3.Variation of DO in the experimental points and stations during May and August.

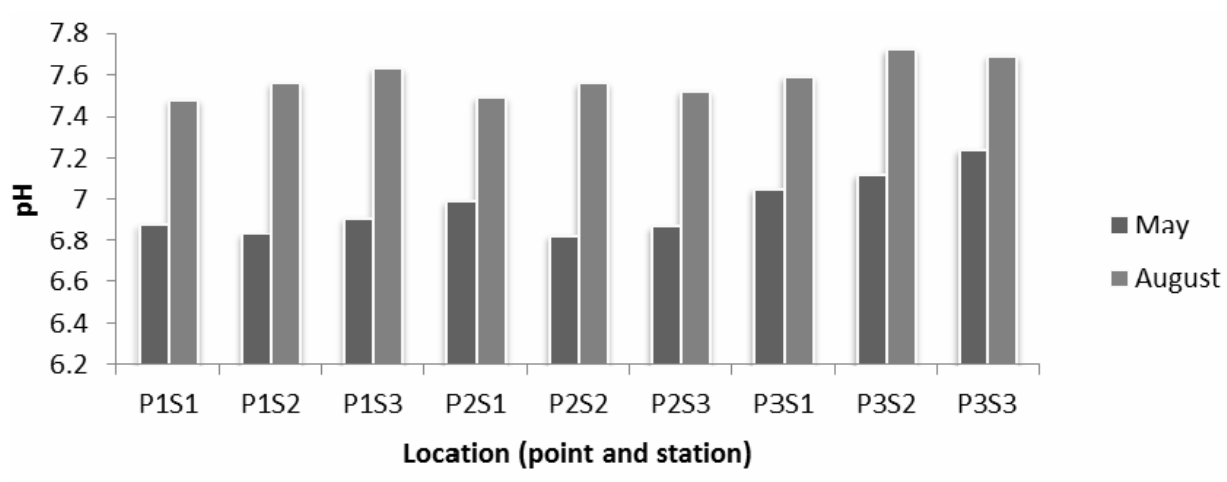

Fig. 4. Variation of $\mathrm{pH}$ in the experimental points and stations during May and August.

Hardness of water is due to the presence of chloride, sulfate, carbonate, bicarbonate etc. salt of $\mathrm{Ca}^{2+}$ and $\mathrm{Mg}^{2+}$. Results showed that in wet season the hardness of water was comparatively higher than that in the dry season (Fig. 5). According to the DoE (Department of Environment 2003) standard, the permissible limit of hardness of drinking water is 200 to $500 \mathrm{ppm}$. The results revealed that at both seasons the Louhajong river water is suitable for fish culture. The highest hardness measured as $254 \mathrm{ppm}$ at the Oloa (P-3) in station 2 (S-2), during the wet season (Table 2) and the lowest was $100 \mathrm{ppm}$ at the Dighulia (P-1) in station 1 (S-1), during dry season (Table 1).

Water that contains less than $500 \mathrm{ppm}$ of dissolved solid is generally satisfactory for the domestic use and other industrial purposes. Water that contains more than $500 \mathrm{ppm}$ of dissolved solids usually contains minerals that give it a distinctive taste or make it unsuitable for human 
consumption. A maximum TDS value of $400 \mathrm{ppm}$ is permissible for diverse fish production (Chhatwal 1998). In the present study, the highest and lowest TDS values (532 and $81 \mathrm{ppm}$ ) were observed in dry and wet seasons at Dighulia (P-1) (Tables 1-2) and the lowest value 81ppm was found in Wet season at the same point (Table 2) respectively. During the dry season TDS values were significantly higher in every point as compared to the wet season (Fig. 6). It is apparent that the water in the wet season is suitable for fish production, but not in the dry season.

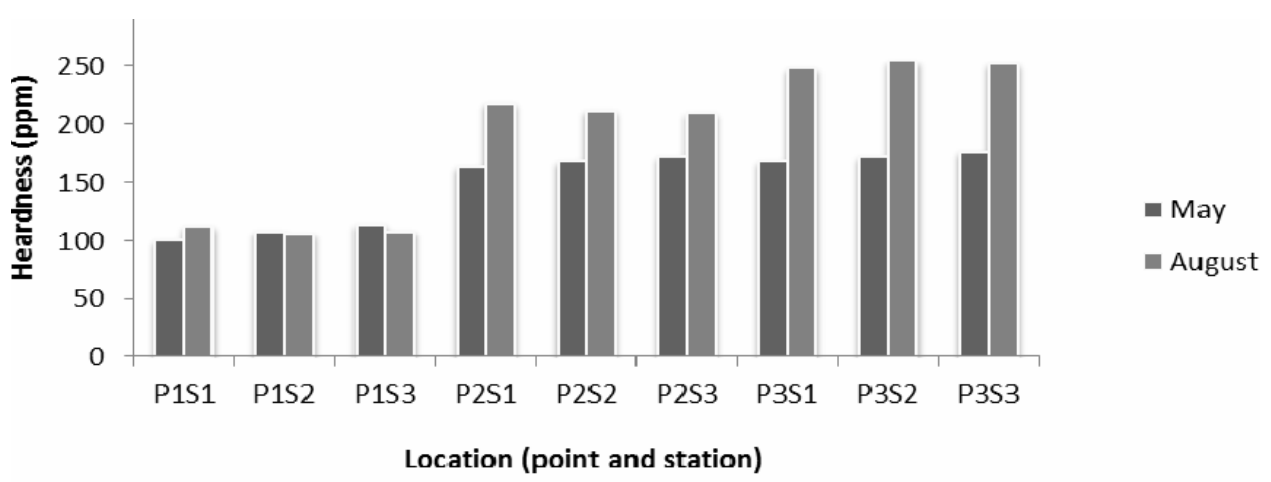

Fig. 5. Variation of hardness in the experimental points and stations during May and August.

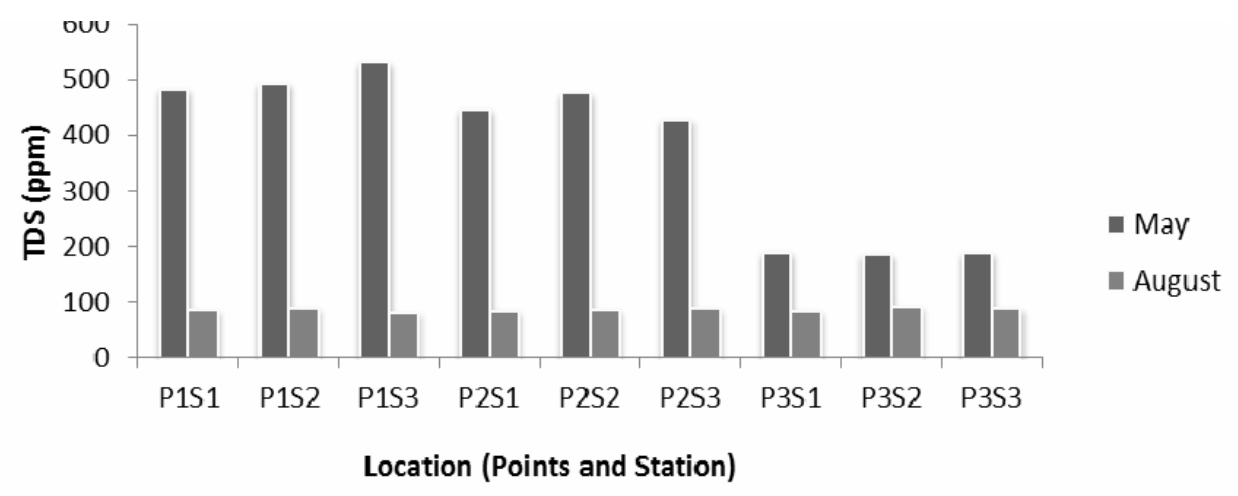

Fig. 6. Variation of TDS in the experimental points and stations during May and August.

Water alkalinity ranges from 154 to $332 \mathrm{mg} / \mathrm{l}$ in dry season (Table 1) and 56 to $82 \mathrm{mg} / \mathrm{l}$ in wet season (Table 2). According to Ehiagbonare and Ogunrinde (2010), the alkalinity of unpolluted river water would be 171.2 to $235.5 \mathrm{mg} / \mathrm{l}$. The present results showed that during the dry season alkalinity range was higher than the standard value except in Oloa (P-3) whereas in wet season it was within the standard value (Fig. 7). 
According to Ehiagbonare and Ogunrinde (2010), the acidity of unpolluted river water would be 171.2 to $235.5 \mathrm{mg} / \mathrm{l}$. The results showed that acidity ranges from 58 to $276 \mathrm{mg} / \mathrm{l}$ in dry season (Table 1) and 26 to $48 \mathrm{mg} / \mathrm{l}$ in wet season (Table 2). During the dry season acidity range has exceeded the standard value in Dighulia (P-1) whereas in wet season it was within the standard value (Fig. 8).

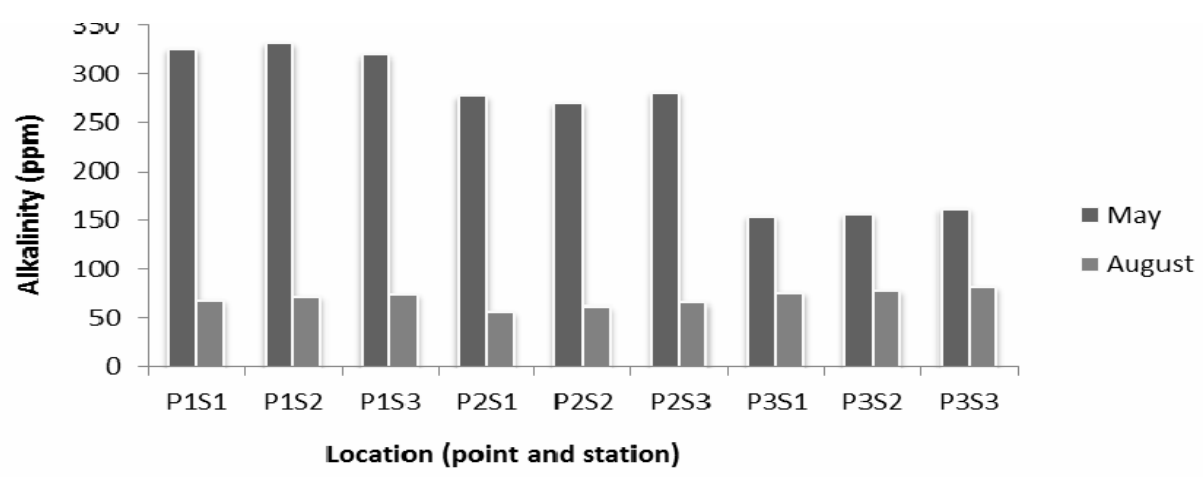

Fig. 7. Variation of alkalinity in the experimental points and stations during May and August.

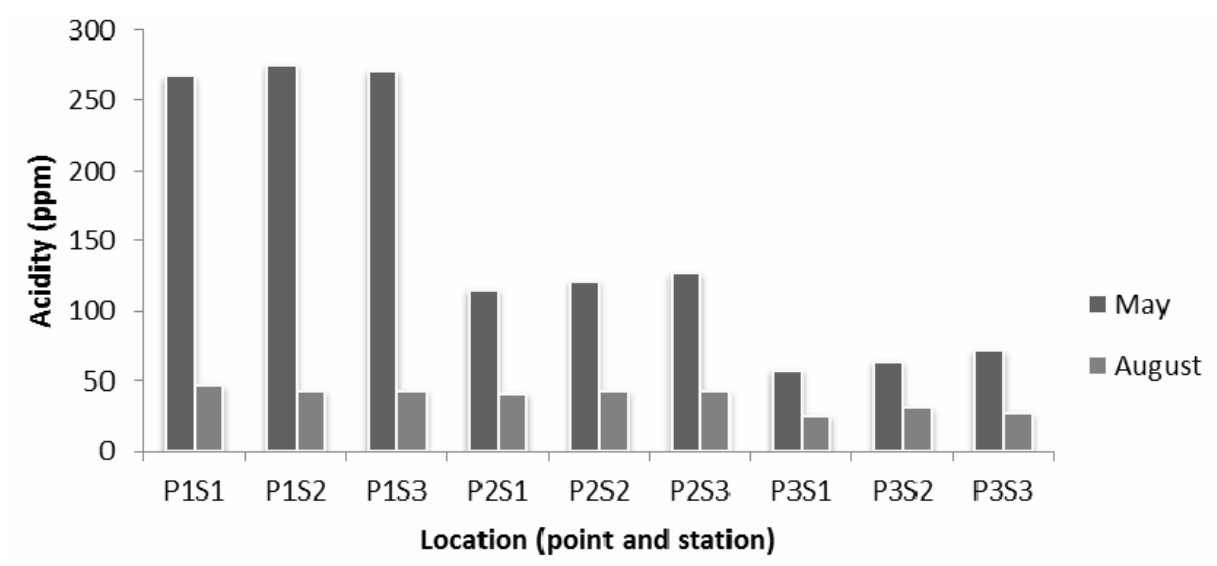

Fig. 8 . Variation of acidity in the experimental points and stations during May and August.

\section{Conclusion}

At wet season Louhajong river is suitable for fish culture and other purposes than the dry season. Some feasible options could be followed such as uncontrolled waste dumping should be properly regulated to minimize its effects on the river as well as on the surrounding environment and awareness should be built up among the people about the environmental degradation due to dumping of solid waste, sewage and industrial effluents. 


\section{References}

BCAS (Bangladesh Centre for Advanced Studies) 2004. The state of Bangladeshi water, Series 5, Bangladesh Centre for Advanced Studies, Dhaka, Bangladesh.

Bhuiyan, M.A. H., M.A. Rakib, S.B. Dampare, S. Ganyaglo, and S. Suzuki 2010. Surface water quality assessment in the central part of Bangladesh using multivariate analysis. KSCE Journal of Civil Engineering 15(6): 995-1003.

Boyd, C.E. 1982. Water Quality Management for Pond Fish Culture. Elsevier, the Netherlands. p. 318.

Chhatwal, G.R. 1998. Encyclopedia of Environmental Biology, Anmol Pub. Pvt. Ltd., New Delhi, India. 2: 287-301.

Das, B. 1997. Fisheries and Fisheries Resources Management. Bangla Academy, Dhaka, Bangladesh. pp. 153-155.

Dara S.S. 2002. A text Book of environmental Chemistry and pollution Control. S. Chand and Company Limited, New Delhi. p. 216.

DoE/BEMP 2003. Fourth Dhaka Water Supply Project. Dhaka Water Resource Management Programme.

ECR (The Environment Conservation Rules) 1997. The Environmental Conservation Rules, Government of the people`s Republic of Bangladesh. Ministry of Environment and Forest (MoEF). pp. 205-207.

EGIS II (Environment and GIS support project for water sector planning) 2002. Water quality approach: Draft final report. Ministry of Water Resources, Government of the People’s Republic of Bangladesh.

Ehiagbonare, J. E. and Y. O. Ogunrinde 2010. Physico-chemical analysis of fish pond waterin Okadaand its environs, Nigeria. African Journal of Biotechnology 9(36): 5922-5928.

EQS (Environmental Quality Standard) 1997. Bangladesh Gazette, Registered nr. DA-1, Ministry of Environment, Government of Bangladesh.

Francis, C.H. 1994. Accumulation and disponibilidad de metals pesados en suelos regados con agus residualses en Distrito de Riego 03, Tula, Hgo. Rev. Inter. Contam. Ambient 10: 15-21.

Haque M. I. 2008. Water resources management in Bangladesh. Anushilan, Chuadanga and Dhaka. pp. 24-84.

Kudesia, V.P. 1990. Industrial Pollution. Progati Prokashan. India.

Rabbani, G. and M. I. Sharif 2005. Dhaka City - state of Environment (SoE) 2005. UNEP in collaboration with BCAS and DoE. p. 40.

Rahman, A.K.M.L., M. Islam, M.Z. Hossain and M.A. Ahsan, 2012. Study of the seasonal variations in Turag river water quality parameters. African Journal of Pure and Applied Chemistry 6(10): 144-148.

Razo, I., L. Carrizales, J. Castro, B. F. Diaz and M. Moroy 2004. Arsenic and Heavy Metal Pollution of Soil, Water and Sediments in a semi-arid Climate Mining area in Mexico. Water, air, Soil Poll. 152(1-4): 129-152.

Sawyer C.N., P.L. McCarty and G.F. Parkin 2003. Chemistry for Environmental Engineering and Science. (5th ed.). New York: McGraw-Hill.

Trivedy R.K. and P.K. Goel 1984. Chemical and biological methods for water pollution studies. Environmental publications, KARAD. pp. 42-74. 